\title{
Prevalence and Resistance Profiles of Enteropathogenic and Shiga Toxin- Producing Escherichia coli in Diarrheic Calves in Mashhad and Garmsar Districts, Iran
}

\author{
Mahdi Askari Badouei ${ }^{1, *}$; Samad Lotfollahzadeh ${ }^{2}$; Moein Arman $^{3}$; Masoud Haddadi ${ }^{3}$ \\ ${ }^{1}$ Department of Pathobiology, Faculty of Veterinary Medicine, Garmsar Branch, Islamic Azad University, Garmsar, IR Iran \\ ${ }^{2}$ Department of Large Animal Internal Medicine, Faculty of Veterinary Medicine, University of Tehran, Tehran, IR Iran \\ ${ }^{3}$ Faculty of Veterinary Medicine, Garmsar Branch, Islamic Azad University, Garmsar, IR Iran \\ ${ }^{*}$ Corresponding author: Mahdi Askari Badouei, Department of Pathobiology, Faculty of Veterinary Medicine, Garmsar Branch, Islamic Azad University, Garmsar, IR Iran. Tel: +98- \\ 2334252121, Fax:+98-2334252020, E-mail: askari@iau-garmsar.ac.ir, mic.consult@gmail.com
}

Received: August 16, 2014; Revised: August 23, 2014; Accepted: August 28, 2014

\begin{abstract}
Background: Shiga toxin-producing Escherichia coli (STEC) strains are considered as one of the most important widespread food-borne pathogens, which cause diarrhea and life threatening diseases, such as hemolytic uremic syndrome, in humans. More recently, the STEC strains have also been incriminated to cause diarrhea and hemorrhagic colitis in calves; enteropathogenic E. coli (EPEC) also causes diarrhea in neonate animals.

Objectives: This study aimed to study the prevalence and antibacterial resistance patterns of STEC and EPEC in fecal samples from diarrheic calves in Mashhad and Garmsar districts, Iran.

Materials and Methods: A total of 115 fecal samples were collected from diarrheic animals, 75 from Mashhad and 40 from Garmsar districts. A total of $146 \mathrm{E}$. coli isolates were obtained from culture and subjected to multiplex-PCR assay targeting stx1, stx2, eaeA and ehly virulence genes. The antibacterial resistance patterns of the virulence-positive isolates were determined using disc diffusion method.

Results: Eight samples (6.9\%) carried the strains with positive results for at least one of the tested virulence genes. Five samples (4.3\%) contained the stx-positive strains (STEC) and three (2.6\%) carried the eaeA-positive and stx-negative strains, which were categorized as EPEC. In nine virulence-positive E. coli isolates, $\operatorname{st} x 1(\mathrm{n}=6)$ was the predominant virulence gene, followed by ehly $(\mathrm{n}=5)$, eae $(\mathrm{n}=4)$, and stx2 $(\mathrm{n}=$ 2). Antibacterial resistance patterns of virulence-positive isolates were also determined and nine resistance profiles were discriminated; higher rates of resistance were observed in isolates from Mashhad.

Conclusions:This study indicated that other pathologic factors might play a more important role in calf diarrhea in the studied areas, but public health significance of these strains should not be overlooked.
\end{abstract}

Keywords:STEC; EPEC; Calf Diarrhea; Antibacterial Resistance

\section{Background}

Escherichia coli strains that produce Shiga toxins are called Shiga toxin-producing E. coli (STEC). Shiga toxins are classified into two types that are encoded by stx 1 and stx2 genes. Intimin, another important virulence factor encoded by the eaeA gene, mediates the intimate attachment of bacteria to the intestinal villi and induces attaching and effacing lesions (A/E) (1-3). The ehly gene is located on a 60-MDa virulence plasmid, and encodes for enterohemolysin, a distinct product from alpha hemolysin of E. coli (4). Shiga toxin-producing strains, which also possess eaeA, and ehly genes, are preferably termed enterohemorrhagic E. coli (EHEC). In humans, EHEC strains are the potential sources for outbreaks of hemorrhagic colitis (HC) and hemolytic uremic syndrome (HUS) worldwide $(5,6)$. STEC not only cause life threatening diseases in humans, but also is incriminated to cause diarrhea and hemorrhagic enterocolitis (HC) in calves $(7,8)$. Different serotypes of STEC that might be associated with diarrhea in calves (mainly $\mathrm{O} 5, \mathrm{O} 26$, and $\mathrm{O118}$ ) have been recognized (1). Surveying the prevalence of STEC and EPEC in animals in different geographical areas is important to monitor the epidemiology of infection with pathogenic E. coli strains.

\section{Objectives}

The aim of the present study was to investigate the prevalence of STEC and EPEC strains in diarrheic calves, which were younger than five weeks old, in Garmsar and Mashhad districts, Iran. The major virulence factors of STEC and EPEC and antibacterial resistance profiles were also determined. 


\section{Materials and Methods}

\subsection{Specimen Collection and Escherichia coli Strains}

Fecal samples were obtained from 115 diarrheic calves in geographically separate farms, located around Mashhad and Garmsar districts. Farms in Garmsar were traditional ones with generally less than 30 animals per farm. All farms in Mashhad were industrial dairy farms. Animals that had recent history of antimicrobial therapy were excluded from sampling. A total of 75 samples were obtained from Mashhad and 40 samples from Garmsar. Specimens were collected using sterile swabs from younger than 30-day-old calves with symptoms of diarrhea or dysentery at the time of sampling. Specimens were sent to the laboratory in Amies transport medium (Difco, USA) and were transferred on MacConkey agar (Merck, Germany) and Sorbitol MacConkey agar (SMAC) (Quelab, Canada). One suspected colony was randomly selected from each culture including lactose fermenting colonies on MacConkey agar and sorbitol-negative colonies on SMAC. All isolates were confirmed by biochemical tests including conventional lactose and glucose fermentation (using TSI medium), urease, indole, methyl red, voges proskauer, citrate, and lysine decarboxylase (9)

\subsection{Detection of Virulence Genes by Multiplex-PCR}

Confirmed E. coli strains were subjected to multiplex-PCR assay, specific for four major virulence genes of STEC and EPEC. Total genomic DNA was extracted from overnight LB agar culture (Merck, Germany) by the boiling method, as was described previously (10). The supernatant was used as template in the PCR mixture. In multiplex-PCR, four pairs of specific primers were used for stx1, stx2, eae, and ehly genes as described by Paton and Paton (1998) (11). Amplification was performed in a total volume of $25 \mu \mathrm{L}$ containing: prepared DNA, $3 \mu \mathrm{L} ; 0.3 \mu \mathrm{M}$ of each oligonucleotide primer; dNTP mix, $0.2 \mathrm{mM} ; \mathrm{MgCl}_{2}, 2 \mathrm{mM} ; 10 \times$ PCR buffer, $2.5 \mu \mathrm{L}$; Taq DNA polymerase (Cinnagen, Iran), one unit; and PCR grade water, up to $25 \mu \mathrm{L}$. Samples were subjected to 35 cycles of touchdown PCR, each consisting of one-minute denaturation at $95^{\circ} \mathrm{C}$, two-minute annealing at $65^{\circ} \mathrm{C}$ for first ten cycles, which was decreased to $60^{\circ} \mathrm{C}$ by cycle 15 , and 1.5 -minute elongation at $72{ }^{\circ} \mathrm{C}$, which was increased to 2.5 minutes from cycles 25 to 35 . The PCR products were electrophoresed on $2 \%$ agarose gel for 90 minutes at $85 \mathrm{v}$ and were visualized by staining with ethidium bromide. Positive results in PCR reactions were recorded by comparing the specific bands with 100bp-plus molecular size marker (Fermentas, Lithuania). Positive controls (O157:H7, Tehran University, collection strain) and negative control (sterile water) were included in all PCR reactions.

\subsection{Antimicrobial Susceptibility Testing}

Antimicrobial susceptibilities of the strains that yielded positive results in the PCR assay were determined on Mueller-Hinton agar (Merck, Germany) by Kirby- Bauer method, according to Clinical and Laboratory Standard Institute (CLSI) protocol (12). Fourteen commercial antibacterial discs (Padtan Teb, Iran) from different classes, which were generally used in veterinary and human medicine in Iran, were employed. The discs included amoxicillin-clavulanate (AMC, $30 \mu \mathrm{g})$, gentamicin (G, 10 $\mu \mathrm{g})$, neomycin (N, $30 \mu \mathrm{g})$, doxycycline (D, $30 \mu \mathrm{g})$, florfeni$\mathrm{col}(\mathrm{FF}, 30 \mu \mathrm{g})$, trimethoprim-sulfamethoxazole (STX, 25 $\mu \mathrm{g})$, trimethoprim (TMP, $5 \mu \mathrm{g})$, ceftriaxone (CRO, $30 \mu \mathrm{g}$ ), cefixime (CM, $5 \mu \mathrm{g})$, enrofloxacin (NFX, $5 \mu \mathrm{g})$, furazolidone $(\mathrm{FR}, 100 \mu \mathrm{g})$, flumequine (FM, $30 \mu \mathrm{g})$, lincospectin (LS, 150 $\mu \mathrm{g})$, and Fosbac $(200 \mu \mathrm{g})$.

\section{Results}

A total of 146 isolates were confirmed as E. coli through conventional biochemical tests with 96 from 75 samples from Mashhad and 50 from 40 samples in Garmsar. In multiplex-PCR assay, nine isolates from eight calves had at least one of the tested virulence genes. Two isolates from a diarrheic calve in Garmsar had produced positive results in the PCR assay; one isolate harbored only the stx1 (isolate No. 7) and the other one had stx1, stx2, and ehly genes (isolate No. 8) (Table 1). Overall, eight calves (6.9\%) carried the strains that were positive for at least one of the tested virulence genes (EPEC or STEC). Among nine virulence-

\begin{tabular}{|c|c|c|c|c|c|c|c|}
\hline \multirow[t]{2}{*}{ Strain No. } & \multicolumn{4}{|c|}{ Virulence Genes } & \multirow[t]{2}{*}{ Pathogenic Type } & \multirow[t]{2}{*}{ Age, d } & \multirow[t]{2}{*}{ Isolate's Origin } \\
\hline & stx1 & stx2 & eaeA & ehly & & & \\
\hline 1 & - & - & + & + & EPEC & 7 & Mashhad \\
\hline 2 & - & - & + & - & EPEC & 8 & Mashhad \\
\hline 3 & - & - & + & + & EPEC & 8 & Mashhad \\
\hline 4 & + & - & - & - & STEC & 7 & Mashhad \\
\hline 5 & + & - & - & - & STEC & 5 & Mashhad \\
\hline 6 & + & - & + & + & STEC & 10 & Garmsar \\
\hline 7 & + & - & - & - & STEC & 10 & Garmsar \\
\hline 8 & + & + & - & + & STEC & 10 & Garmsar \\
\hline 9 & + & + & - & + & STEC & 17 & Garmsar \\
\hline
\end{tabular}

a Abbreviations: EPEC, enteropathogenic Escherichia coli; and STEC, Shiga toxin-producing Escherichia coli. 
Askari Badouei M et al.

\begin{tabular}{|c|c|c|c|c|c|c|c|c|c|}
\hline \multirow[t]{2}{*}{ Strain No. } & \multicolumn{9}{|c|}{ Antibiotic } \\
\hline & GM & CFM & FF & D & STX & LS & $\mathbf{N}$ & NFX & TMP \\
\hline 1 & $S$ & $S$ & I & $\mathrm{R}$ & $S$ & $\mathrm{R}$ & $S$ & $S$ & $S$ \\
\hline 2 & $S$ & I & $\mathrm{R}$ & $\mathrm{R}$ & $\mathrm{R}$ & $\mathrm{R}$ & I & S & $\mathrm{R}$ \\
\hline 3 & I & $S$ & I & I & $\mathrm{R}$ & $\mathrm{R}$ & $\mathrm{R}$ & I & $\mathrm{R}$ \\
\hline 4 & $S$ & $S$ & $S$ & $\mathrm{R}$ & $\mathrm{R}$ & $\mathrm{R}$ & I & S & $\mathrm{R}$ \\
\hline 5 & I & S & I & I & S & $\mathrm{R}$ & I & S & $S$ \\
\hline 6 & $S$ & $S$ & $S$ & $\mathrm{R}$ & $S$ & I & I & S & $S$ \\
\hline 7 & S & S & $S$ & I & S & $\mathrm{R}$ & I & S & $S$ \\
\hline 8 & I & $S$ & $S$ & $\mathrm{R}$ & $S$ & $S$ & I & S & S \\
\hline 9 & S & S & $S$ & $S$ & $S$ & $S$ & I & $S$ & $S$ \\
\hline
\end{tabular}

positive E. coli isolates, stx1 $(\mathrm{n}=6)$ was the predominant virulence gene, followed by ehly $(\mathrm{n}=5)$, eae $(\mathrm{n}=4)$, and stx2 $(n=2)$. Five calves $(4.3 \%)$ carried the E. coli strains with a variant of stx genes (STEC), and three calves (2.6\%) carried the eaeA-positive and stx-negative strains, which were categorized as EPEC. In Mashhad, two calves (2.6\%) carried the STEC, and three calves (4\%) carried EPEC strains. None of the isolates from Mashhad was positive for stx2. In Garmsar, 10\% of cultured fecal samples had positive results for STEC, but EPEC was not detected (Table 1). Antibacterial susceptibility testing of nine isolates revealed nine distinct resistance patterns (Table 2). All strains were sensitive to Fosbac, flumequine, furazolidone, and ceftriaxone, but resistant to amoxicillin-clavulanate.

\section{Discussion}

In humans, STEC strains are considered as major cause of HC and HUS worldwide. The disease in human is primarily a food-borne infection, but contact with carrier animals might be a secondary route of infection (13). In addition, infections with STEC have been described in a wide range of domestic and wild animal species, but the natural pathogenic role has been demonstrated only in weaning pigs, young calves, and dogs. Typically, the diarrheagenic STEC strains in calves harbor stx1 and eaeA genes $(6,7)$. This study investigated the presence of major virulence factors of EPEC and STEC among 146 isolates from 115 diarrheic calves in Mashhad and Garmsar districts using an efficient multiplex-PCR assay. The results showed the higher importance of EPEC in Mashhad district while no EPEC was detected in diarrheic calves in Garmsar. Interestingly, two STEC strains from Mashhad had negative results for eaeA gene and only harbored the stx1 gene. One strain from Garmsar harbored stx1, eaeA, and ehly genes simultaneously, which was categorized as EHEC. It should be noted that EHEC strains have higher pathogenic capacity and are of particular concern in hu- man diseases and outbreaks (6). Although EPEC are considered to induce diarrhea in different animal species and calves (9), very little information on the importance of EPEC in neonate ruminants is available. In the present study primers for eaeA gene were able to target a conserved region of the intimin gene (eae) between EHEC and EPEC; therefore, strains with positive results for eae (not harboring stx) are considered as EPEC (11). The results showed that three calves (2.6\%) carried the eaeA-positive and $s t x$-negative EPEC strains; two of these isolates also carried the ehly gene. Presence of ehly gene in these eaepositive strains suggests that these might be the former EHEC, which lost the Shiga toxin genes during infection or subculture $(14,15)$. The $s t x 1$ was the predominant virulence gene in the present study and all of the six STEC isolates carried this virulence factor, of which two also carried the stx2 gene. Interestingly, most of the strains in the current study were isolated from seven to tenday-old diarrheic calves (Table 1). Our findings support other studies, which reported higher frequency of stx 1 in calves. Leomil et al.(2003) documented higher frequency of carriage of $s t x 1$ in diarrheic calves in Brazil (16). Orden et al. studied isolates from 221 diarrheic calves and found that $69.8 \%$ of STEC strains harbor stx1, 20.9\% stx2, and 9.3\% stx1/stx2 genes (17). Wieler et al. evaluated 176 diarrheic calves and found that $61 \%, 7 \%$, and $1 \%$ of STEC strains harbored stx1, stx2, and stx1/stx2, respectively (18). In our previous study, the combination of stx1, eaeA, and ehly genes was the predominant virulence profile among 200 diarrheic calves in Iran (19). In contrast, some studies have detected stx2 as a dominant Shiga toxin type among STEC from calves (20-22). It should be noted that geographical area and time of sampling are important factors in epidemiology of STEC in animals.

Antibacterial susceptibility testing of nine isolates revealed nine distinct resistance patterns, which indicated the heterogeneity of isolated strains from calves. 
All strains were shown to be sensitive to Fosbac, flumequine, furazolidone, and ceftriaxone, but resistant to amoxicillin-clavulanate. Resistance to doxycycline and lincospectin was also substantial in this study. We recently reported the considerable resistance to amoxicillin and tetracyclines in STEC isolates from pigeons in Iran, which was similar to the results of the present study (23). Comparison of antibacterial resistance between isolates from Mashhad and Garmsar showed that the strains from Mashhad were multiple-resistant to three or more antibacterial agents (except one isolate); this might be the result of limited use of antibiotics in traditional farming system, which is common in Garmsar. Similar to infantile diarrhea in humans, calf diarrhea has also several pathoetiologies such as infection with viral, parasitic, or bacterial agents $(8,24)$. This study indicated that other causative agents might play a more important role in calf diarrhea in the studied areas, but because of the public health significance of STEC, the characteristics of these isolates from calves should not be overlooked.

\section{Authors' Contributions}

The study was designed, drafted, analyzed, and supervised by Mahdi Askari Badouei. The results were analyzed and the draft was reviewed by Samad Lotfollahzadeh. Moein Arman and Masoud Haddadi performed the laboratory procedures.

\section{Funding/Support}

This study was partly supported by research council of Islamic Azad University, Garmsar Branch.

\section{References}

1. Orden JA, Yuste M, Cid D, Piacesi T, Martinez S, Ruiz-Santa-Quiteria JA, et al. Typing of the eae and espB genes of attaching and effacing Escherichia coli isolates from ruminants. Vet Microbiol. 2003;96(2):203-15.

2. Gyles CL. Shiga toxin-producing Escherichia coli: an overview. $J$ Anim Sci. 2007;85(13 Suppl):E45-62.

3. Blanco M, Blanco JE, Dahbi G, Alonso MP, Mora A, Coira MA, et al. Identification of two new intimin types in atypical enteropathogenic Escherichia coli. Int Microbiol. 2006;9(2):103-10.

4. Lee JH, Hur J, Stein BD. Occurrence and characteristics of enterohemorrhagic Escherichia coli $\mathrm{O} 26$ and $\mathrm{O} 111$ in calves associated with diarrhea. Vet J. 2008;176(2):205-9.

5. Wani SA, Hussain I, Fayaz I, Mir MA, Nishikawa Y. Subtype analysis of stx1, stx2 and eae genes in Shiga toxin-producing Escherichia coli (STEC) and typical and atypical enteropathogenic E. coli (EPEC) from lambs in India. Vet J. 2009;182(3):489-90.

6. Caprioli A, Morabito S, Brugere H, Oswald E. Enterohaemorrhagic Escherichia coli: emerging issues on virulence and modes of transmission. Vet Res. 2005;36(3):289-311.

7. Gyles CL, Fairbrother JM. Pathogenesis of Bacterial Infections in Animals. 4 ed: Wiley-Blackwell;2010.
8. Radostits OM, Gay CC, Hinchcliff KW, et al. . Veterinary Medicine: A textbook of the diseases of cattle, horses, sheep, pigs and goats, . 10 ed: Saunders Ltd; 2007.

9. Songer JG, Post KW. Veterinary Microbiology, Bacterial and fungal agents of animal disease 1 ed:WB Saunders; 2005.

10. Salehi TZ, Tadjbakhsh H, Atashparvar N, Nadalian MG, Mahzounieh MR. Detection and identification of Salmonella Typhimurium in bovine diarrhoeic fecal samples by immunomagnetic separation and multiplex PCR assay. Zoonoses Public Health. 2007;54(67):231-6.

11. Paton AW, Paton JC. Detection and characterization of Shiga toxigenic Escherichia coli by using multiplex PCR assays for stx1, stx2, eaeA, enterohemorrhagic E. coli hlyA, rfbO111, and rfbO157. J Clin Microbiol. 1998;36(2):598-602.

12. Clinical and Laboratory Standards Institute. . Performance Standards for Antimicrobial Susceptibility Testing, approved standard. Wayne, PA. 2008.

13. Steinmuller N, Demma L, Bender JB, Eidson M, Angulo FJ. Outbreaks of enteric disease associated with animal contact: not just a foodborne problem anymore. Clin Infect Dis. 2006;43(12):1596602

14. Bielaszewska M, Kock R, Friedrich AW, von Eiff C, Zimmerhack LB, Karch H, et al. Shiga toxin-mediated hemolytic uremic syndrome: time to change the diagnostic paradigm? PLoS One 2007;2(10).

15. Karch H, Meyer T, Russmann H, Heesemann J. Frequent loss of Shiga-like toxin genes in clinical isolates of Escherichia coli upon subcultivation. Infect Immun. 1992;60(8):3464-7.

16. Leomil L, Aidar-Ugrinovich L, Guth BE, Irino K, Vettorato MP, Onuma DL, et al. Frequency of Shiga toxin-producing Escherichia col (STEC) isolates among diarrheic and non-diarrheic calves in Brazil. Vet Microbiol. 2003;97(1-2):103-9.

17. Orden JA, Ruiz-Santa-Quiteria JA, Cid D, Garcia S, Sanz R, de la Fuente R. Verotoxin-producing Escherichia coli (VTEC) and eaepositive non-VTEC in 1-30-days-old diarrhoeic dairy calves. Vet Microbiol.1998;63(2-4):239-48.

18. Wieler LH, Vieler E, Erpenstein C, Schlapp T, Steinruck H, Bauer feind R, et al. Shiga toxin-producing Escherichia coli strains from bovines: association of adhesion with carriage of eae and other genes. J Clin Microbiol. 1996;34(12):2980-4

19. Badouei MA, Salehi TZ, Khorasgani MR, Tadjbakhsh H, Brujeni GN, Nadalian MG. Virulence gene profiles and intimin subtypes of Shiga toxin-producing Escherichia coli isolated from healthy and diarrhoeic calves. Vet Rec. 2010;167(22):858-61.

20. Beutin L, Geier D, Zimmermann S, Aleksic S, Gillespie HA, Whittam TS. Epidemiological relatedness and clonal types of natura populations of Escherichia coli strains producing Shiga toxins in separate populations of cattle and sheep. Appl Environ Microbiol. 1997;63(6):2175-80

21. Mazhaheri NFR, Behzadian NG, Zahraei-Salehi T. , et al. . Evaluation of ehxA, stx1 and stx2 virulence gene prevalence in cattle Escherichia coli isolates by Multiplex PCR. Arch Razi Ins 2005;60(1):55-66.

22. Dastmalchi SH, Ayremlou N. Characterization of Shiga toxin-producing Escherichia coli (STEC) in feces of healthy and diarrheic calves in Urmia region, Iran. Iran J Microbiol. 2012;4(2):63-9.

23. Askari Badouei M, Zahraei Salehi T, Koochakzadeh A, Kalantari A, Tabatabaei S. Molecular characterization, genetic diversity and antibacterial susceptibility of Escherichia coli encoding Shiga toxin $2 \mathrm{f}$ in domestic pigeons. Lett Appl Microbiol. 2014; 59(4):370-6.

24. Sadeghian A, Hamedi A, Sadeghian M, Sadeghian H. Incidence of rotavirus diarrhea in children under 6 years referred to the Pediatric Emergency and Clinic of Ghaem Hospital, Mashhad, Iran. Acta Med Iran 2010;48(4):263-5. 